medRxiv preprint doi: https://doi.org/10.1101/2020.04.09.20058909; this version posted April 11, 2020. The copyright holder for this preprint (which was not certified by peer review) is the author/funder, who has granted medRxiv a license to display the preprint in perpetuity.

All rights reserved. No reuse allowed without permission.

\title{
Classification of COVID-19 in intensive care patients: towards rational and effective triage
}

Xiaofan $\mathrm{Lu}^{1+}, \mathrm{PhD}$; Yang Wang ${ }^{2 \dagger}, \mathrm{MD}$; Taige $\mathrm{Chen}^{3 \dagger}, \mathrm{MD}$; Yongsheng $\mathrm{Li}^{4}, \mathrm{MD}$; Jun Wang ${ }^{5^{*}}, \mathrm{MD}$;

Fangrong $\operatorname{Yan}^{1^{*}}, \mathrm{PhD}$

\section{Author Affiliations}

${ }^{1}$ State Key Laboratory of Natural Medicines, Research Center of Biostatistics and Computational Pharmacy, China Pharmaceutical University, Nanjing, China

${ }^{2}$ Department of Radiology, The Affiliated Nanjing Drum Tower Hospital of Nanjing University Medical School, Nanjing, China

${ }^{3}$ Medical School of Nanjing University, Nanjing, China

${ }^{4}$ Department of Intensive Care Medicine, Tongji Hospital, Tongji Medical College, Huazhong University of Science and Technology, Wuhan, China

${ }^{5}$ Department of Intensive Care Medicine, The First Affiliated Hospital of Soochow University, Suzhou, China

${ }^{\dagger}$ These authors contributed equally.

${ }^{*}$ Corresponding Authors: Jun Wang, MD, Department of Intensive Care Medicine, The First Affiliated Hospital of Soochow University, No. 188 Shizi Street, Suzhou 215006, China (dr wangjun@suda.edu.cn); Fangrong Yan, PhD, State Key Laboratory of Natural Medicines, Research Center of Biostatistics and Computational Pharmacy, China Pharmaceutical University, Nanjing 210009, China (f.r.yan@163.com)

\section{Funding}

This work was supported by the National Key R\&D Program of China (2019YFC1711000), the NOTE: This preprint reports new research that has not been certified by peer review and should not be used to guide clinical practice. 
medRxiv preprint doi: https://doi.org/10.1101/2020.04.09.20058909; this version posted April 11, 2020. The copyright holder for this preprint (which was not certified by peer review) is the author/funder, who has granted medRxiv a license to display the preprint in perpetuity.

All rights reserved. No reuse allowed without permission.

National Natural Science Foundation of China (81973145), the “Double First-Class" University Project (CPU2018GY09), the China Postdoctoral Science Foundation (2019M651805), the Science Foundation of Jiangsu Commission of Health (H2018117), and the Emergency Project for the Prevention and Control of the Novel Coronavirus Outbreak in Suzhou (SYS2020012).

\section{Author Contributions}

Drs J. Wang and Y. Li had full access to all of the data in the study.

Conceptualization: X. Lu.

Acquisition, analysis, or interpretation of data: J. Wang, Y. Wang, X. Lu, T. Chen.

Statistical analysis: X. Lu, F. Yan.

Investigation: X. Lu, T. Chen, Y. Wang, Y. Li.

Drafting of the manuscript editing: X. Lu, T. Chen, Y. Wang.

Funding acquisition: J. Wang, F. Yan.

Supervision: J. Wang, F. Yan.

\section{Data availability}

Dr J. Wang had full access to all of the data in the study. After publication, the data will be made available to others on reasonable requests after approval from the author (J.W, dr_wangjun@suda.edu.cn) and Wuhan Tongji Hospital (Y.L, dr_ysli@126.com).

\section{Word count: 812}


medRxiv preprint doi: https://doi.org/10.1101/2020.04.09.20058909; this version posted April 11, 2020. The copyright holder for this preprint (which was not certified by peer review) is the author/funder, who has granted medRxiv a license to display the preprint in perpetuity.

All rights reserved. No reuse allowed without permission.

\section{Introduction}

Severe acute respiratory syndrome coronavirus 2 (SARS-CoV-2) pneumonia is a newly recognized illness that has spread rapidly around the world. Previous studies on coronavirus disease 2019 (COVID-19) mainly described the general epidemiological, clinical, and radiological features of patients with confirmed infection (1). Little attention has been paid to the clinical characteristics and outcomes of intensive care patients with COVID-19, data of which are scarce but are of paramount importance to reduce mortality. We aimed to bridge the gap between disease classification and clinical outcome in intensive care patients, which could help in individual evaluation and provide effective triage for treatment and management.

\section{Methods}

Data of 306 intensive care patients were obtained from Tongji hospital in Wuhan, China. Patients were hospitalized and admitted to intensive care wards from January 25 to February 25,2020 , who had been diagnosed with infection of SARS-CoV-2 according to WHO interim guidance. Data on the day of admission were collected, including six data categories: demographic information of age and gender, symptoms ([>10\%] fever, fatigue, dry cough, anorexia, myalgia, dyspnea, expectoration, diarrhea), original comorbidities $([>5 \%]$ hypertension, diabetes, cardiovascular disease [CVD], chronic obstructive pulmonary disease [COPD], malignancy), vital signs (respiratory rate, heart rate, blood pressure, $\mathrm{SpO}_{2}, \mathrm{FiO}_{2}$ ), blood routine tests (count of white blood cell [WBC], lymphocyte, neutrophil, platelet and monocyte, red cell distribution width [RDW]) and inflammatory marker measurements 
medRxiv preprint doi: https://doi.org/10.1101/2020.04.09.20058909; this version posted April 11, 2020. The copyright holder for this preprint (which was not certified by peer review) is the author/funder, who has granted medRxiv a license to display the preprint in perpetuity.

All rights reserved. No reuse allowed without permission.

(high-sensitivity C-reactive protein [hs-CRP], interleukin-2 receptor [IL-2R], IL-6, IL-8, IL-10, tumor necrosis factor- $\alpha$ [TNF- $\alpha])$. Clinical outcome was 28-day mortality after admission to intensive care wards. The Ethics Commission of Tongji hospital approved this study, with a waiver of informed consent for the rapid emergence of this epidemic.

A total of 151 intensive care patients with complete medical records were further filtered out for this study. We constructed a fully Bayesian latent variable model for integrative clustering of the six data categories with different distributions (2). Specifically, age was dichotomized with 65-year cutoff according to the literature (3). Outliers were detected by Tukey's method which uses interquartile (IQR) range approach, and outliers ranged above and below the

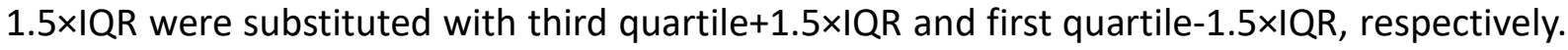
Data magnitude was manually checked and logarithmic transformation was utilized as appropriate; continuous data were further median-centered and scaled for being comparable. Binomial and Gaussian distributions were considered for categorical and continuous variables, respectively, and prior probability for the indicator variable gamma was set to 0.5 for each data category. Appropriate number of clusters was determined by minimizing the Bayesian information criterion. Only features with high posterior probability (e.g., 0.8) were kept. All statistical analyses were conducted with R3.6.2 using a Fisher's exact test for categorical data and a Kruskal-Wallis test for multiple group comparison; Survival rates was generated by Kaplan-Meier curve and analyzed with log-rank test. For unadjusted comparisons, a two-sided $P<0.05$ was considered statistically significant. 
medRxiv preprint doi: https://doi.org/10.1101/2020.04.09.20058909; this version posted April 11, 2020. The copyright holder for this preprint (which was not certified by peer review) is the author/funder, who has granted medRxiv a license to display the preprint in perpetuity.

All rights reserved. No reuse allowed without permission.

\section{Results}

We identified four types of intensive patients with COVID-19, which was tightly associated with clinical outcome (Figure). Characteristics of the four types were described below (Table).

Type A: Extremely poor prognosis and elderly enriched; Dry cough, dyspnea and fatigue were common symptoms; hypertension, diabetes and CVD were common preexisting medical conditions. Patients presented severe respiratory failure, dramatically elevated counts of WBC and neutrophil, and lymphocyte depletion. Remarkable "cytokine storm" occurred, accompanied with later development of ARDS and multiple organ failure.

Type B: Poor prognosis and elderly enriched; dyspnea and cough with expectoration were common symptoms, accompanied with diarrhea and anorexia. Unfavorable respiratory condition and decreased lymphocyte count could be observed. Patients presented imminent "cytokine storm" and high risk of developing ARDS and multiple organ failure later after treatment.

Type C: Intermediate prognosis; symptoms of dry cough and fatigue, and original comorbidity of hypertension were common. Respiratory condition was normal and most laboratory tests were within normal or moderately elevated.

Type D: Favorable prognosis and middle age enriched; primary symptom was cough with 
medRxiv preprint doi: https://doi.org/10.1101/2020.04.09.20058909; this version posted April 11, 2020. The copyright holder for this preprint (which was not certified by peer review) is the author/funder, who has granted medRxiv a license to display the preprint in perpetuity.

All rights reserved. No reuse allowed without permission.

expectoration. Patients had stable breathing and most laboratory tests were in normal range or slightly elevated.

\section{Discussion}

This report, to our knowledge, is the first attempt of dealing with classification of COVID-19 in intensive care patients. The four types are prognosis-related and present a stepwise distribution in age, respiratory condition and inflammatory markers, suggesting the prognostic efficacy of these indicators. The specificity of symptoms does not appear to be strong, but gastrointestinal response (e.g., diarrhea) needs vigilance (4). Unexpectedly, hypertension is more evenly distributed, which contradicts previous study indicating hypertensive with COVID-19 was more likely to be in a high risk of mortality (5). Investigations in larger cohorts are required to provide more evidence.

The study is limited by ignoring the effect of treatment, but we believe that such classification of COVID-19 in intensive care patients could help in early warning of the disease and would provide effective triage for the treatment and management of individual patients, allowing for a more rational allocation of scarce medical resources in a resource constrained environment. 
medRxiv preprint doi: https://doi.org/10.1101/2020.04.09.20058909; this version posted April 11, 2020. The copyright holder for this preprint (which was not certified by peer review) is the author/funder, who has granted medRxiv a license to display the preprint in perpetuity.

All rights reserved. No reuse allowed without permission.

\section{Acknowledgments}

We would like to thank all the hospital staff members for their efforts in collecting the information that was used in this study, and all the patients who consented to donate their data for analysis and the medical staff members who are on the front line of caring for patients.

\section{Conflict of Interest Disclosures}

The authors declare no competing interests. 
medRxiv preprint doi: https://doi.org/10.1101/2020.04.09.20058909; this version posted April 11, 2020. The copyright holder for this preprint (which was not certified by peer review) is the author/funder, who has granted medRxiv a license to display the preprint in perpetuity.

All rights reserved. No reuse allowed without permission.

\section{References}

1. Guan W-j, Ni Z-y, Hu Y, Liang W-h, Ou C-q, He J-x, et al. Clinical Characteristics of Coronavirus Disease 2019 in China. N Engl J Med. 2020. doi: 10.1056/NEJMoa2002032.

2. Mo Q, Shen R, Guo C, Vannucci M, Chan KS, Hilsenbeck SG. A fully Bayesian latent variable model for integrative clustering analysis of multi-type omics data. Biostatistics. 2018;19(1):71-86. doi: 10.1093/biostatistics/kxx017.

3. Yang $X, Y u Y, X u J$, Shu $H$, Liu H, Wu Y, et al. Clinical course and outcomes of critically ill patients with SARS-CoV-2 pneumonia in Wuhan, China: a single-centered, retrospective, observational study. Lancet Respir Med. 2020. doi: 10.1016/S2213-2600(20)30079-5.

4. Liang W, Feng Z, Rao S, Xiao C, Xue X, Lin Z, et al. Diarrhoea may be underestimated: a missing link in 2019 novel coronavirus. Gut. 2020. doi: 10.1136/gutjnl-2020-320832

5. Zhou F, Yu T, Du R, Fan G, Liu Y, Liu Z, et al. Clinical course and risk factors for mortality of adult inpatients with COVID-19 in Wuhan, China: a retrospective cohort study. Lancet. 2020. doi: 10.1016/S0140-6736(20)30566-3 
medRxiv preprint doi: https://doi.org/10.1101/2020.04.09.20058909; this version posted April 11, 2020. The copyright holder for this preprint (which was not certified by peer review) is the author/funder, who has granted medRxiv a license to display the preprint in perpetuity.

All rights reserved. No reuse allowed without permission.

Table. Presenting characteristics of four types of COVID-19 in intensive care patients $(n=151)$

\begin{tabular}{|c|c|c|c|c|}
\hline & $A(n=37)$ & $B(n=45)$ & $C(n=27)$ & $D(n=42)$ \\
\hline Age, years & $77(70-81)$ & $62(52-70)$ & $65(51-74)$ & $53(43-58)$ \\
\hline \multicolumn{5}{|l|}{ Signs and symptoms } \\
\hline Cough & $26(70)$ & 45 (100) & $12(44)$ & $34(81)$ \\
\hline Dyspnea & $24(65)$ & $41(91)$ & $14(52)$ & $13(31)$ \\
\hline Fatigue & $19(51)$ & $27(60)$ & $21(78)$ & $1(2)$ \\
\hline Expectoration & $6(16)$ & $40(89)$ & $1(4)$ & $16(38)$ \\
\hline Diarrhea & $5(14)$ & $20(44)$ & $7(26)$ & $9(21)$ \\
\hline Anorexia & $6(16)$ & $15(33)$ & $9(33)$ & $1(2)$ \\
\hline \multicolumn{5}{|l|}{ Original comorbidities } \\
\hline Hypertension & $20(54)$ & $15(33)$ & $17(63)$ & $8(19)$ \\
\hline Diabetes & $13(35)$ & $6(13)$ & $7(26)$ & $5(12)$ \\
\hline CVD & $15(41)$ & 0 & $6(22)$ & $2(5)$ \\
\hline \multicolumn{5}{|l|}{ Vital signs } \\
\hline Respiratory rate, rpm & $25(20-32)$ & $22(20-26)$ & $20(20-23)$ & $21(20-25)$ \\
\hline $\mathrm{SpO}_{2} / \mathrm{FiO}_{2}$ & 99 (90-158) & $222(100-294)$ & $297(237-336)$ & $298(248-345)$ \\
\hline \multicolumn{5}{|l|}{ Laboratory findings } \\
\hline \multicolumn{5}{|l|}{ Routine blood test } \\
\hline WBCs, $\times 10^{9} / \mathrm{L}$ & $11.1(8.0-15.5)$ & $7.4(5.3-10.2)$ & $5.6(4.5-6.5)$ & $5.2(3.5-7.2)$ \\
\hline $\begin{array}{l}\text { Absolute lymphocytes, } \\
\times 10^{9} / \mathrm{L}\end{array}$ & $0.5(0.3-0.7)$ & $0.7(0.5-1.0)$ & $0.8(0.7-1.2)$ & $1.0(0.7-1.4)$ \\
\hline $\begin{array}{l}\text { Absolute Neutrophils, } \\
\times 10^{9} / \mathrm{L}\end{array}$ & $9.5(7.1-15.0)$ & $5.5(4.3-9.1)$ & $4.2(3.0-5.1)$ & $3.1(2.2-5.0)$ \\
\hline RDW-CV & $13.4(12.8-14.1)$ & $12.2(11.9-12.8)$ & $12.6(11.8-13.0)$ & $12.2(11.8-12.7)$ \\
\hline \multicolumn{5}{|l|}{ Inflammatory marker } \\
\hline hs-CRP, mg/L & $126(76-190)$ & $80(42-109)$ & $19(5-49)$ & $28(10-70)$ \\
\hline IL-2R, U/ml & 1341 (940-1809) & $1038(678-1185)$ & 701 (430-813) & $685(439-928)$ \\
\hline IL-6, pg/ml & $68(37-137)$ & 43 (21-79) & $10(2-20)$ & $14(5-30)$ \\
\hline IL-8, pg/ml & $42(21-95)$ & $21(13-40)$ & $12(7-24)$ & $15(10-21)$ \\
\hline $\mathrm{IL}-10, \mathrm{pg} / \mathrm{ml}$ & $15(9-24)$ & $7(3-11)$ & $3(3-6)$ & $3(3-9)$ \\
\hline TNF- $\alpha, \mathrm{pg} / \mathrm{ml}$ & $15(10-23)$ & $9(8-11)$ & $7(5-9)$ & $8(7-10)$ \\
\hline
\end{tabular}

Continuous variables were described as median (IQR) while categorical variables were expressed as frequencies (\%). All records were measured at admission to intensive care wards.

Multiple group comparison was done with Kruskal-Wallis test; proportions for categorical variables were compared using Fisher's exact test. All calculated $P$ values were less than 0.001 except for respiratory rate $(P=0.004)$.

Abbreviations: CVD: cardiovascular disease; rpm: breaths per minute; $\mathrm{SpO}_{2}$ : peripheral oxygen saturation; $\mathrm{FiO}_{2}$ : fraction of inspired oxygen; WBC: white blood cell; RDW: red cell distribution width. 

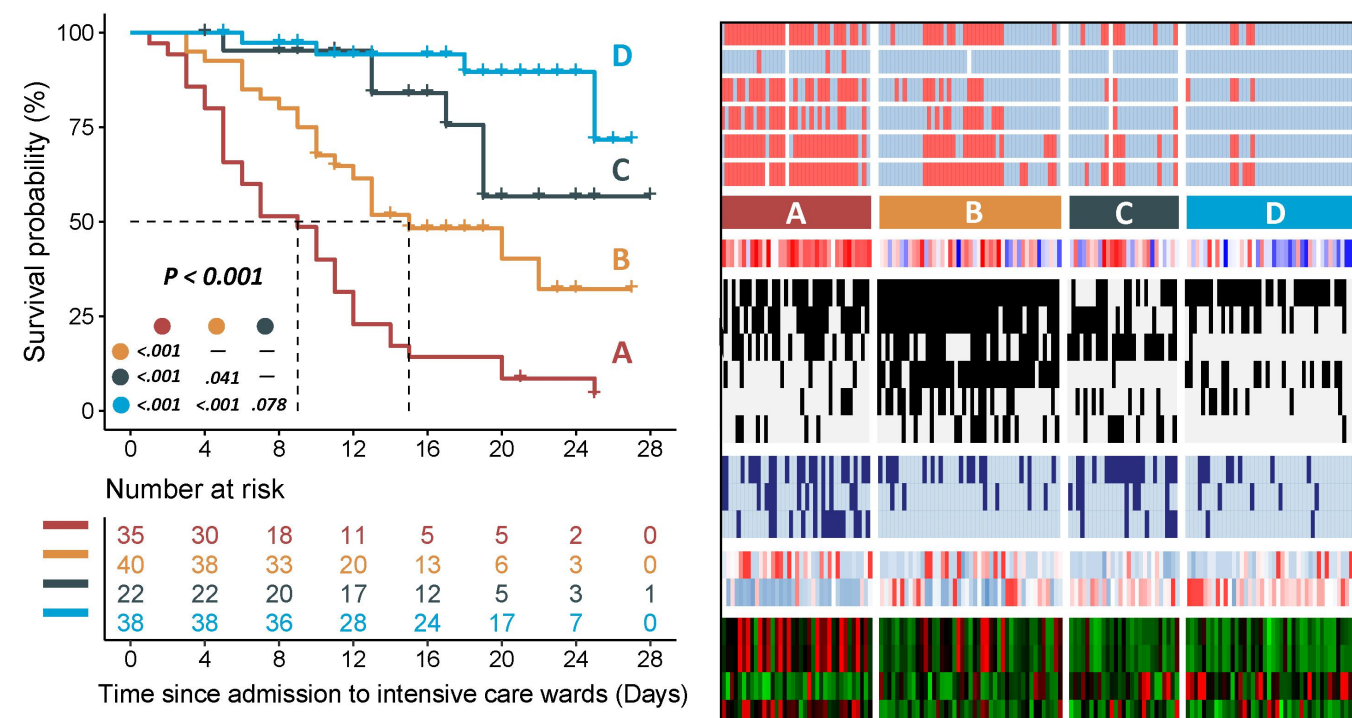

Myocardial damage

Rhabdomyolysis

AKI

DIC
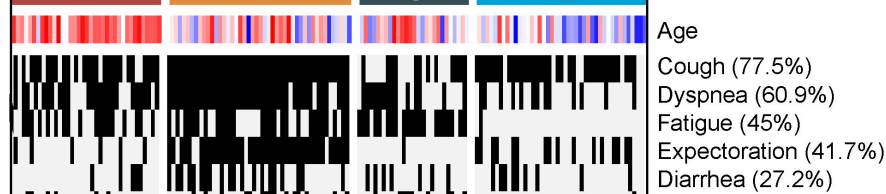

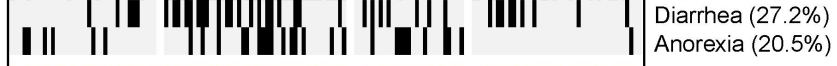
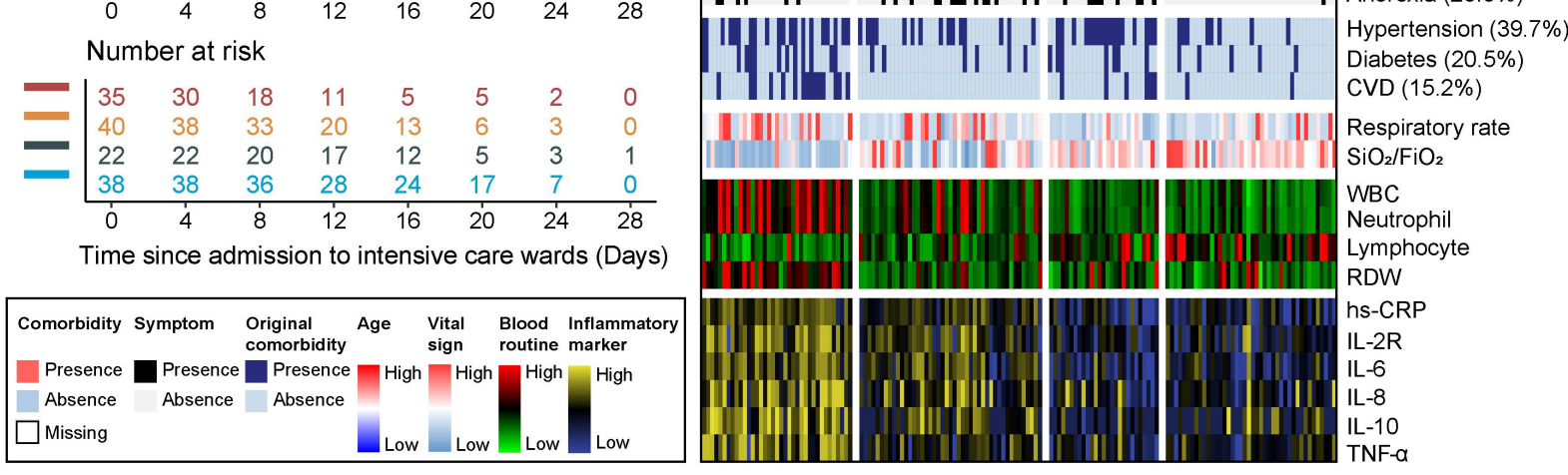

Figure. Clinical landscape of four prognostic types of COVID-19 in intensive care patients. Kaplan-Meier survival curves (left panel) showing differential survival rates; comprehensive heatmap (right panel) delineating clinical landscape of different types of COVID-19, with legend positioning in the left bottom panel. Survival was analyzed with log-rank test and pair-wise comparison was adjusted by Benjamini-Hochberg method. Labels of "high" and "low" were based on data interval instead of clinical reference values. AKI: acute kidney injury; DIC: disseminated intravascular coagulation; ARDS: acute respiratory distress syndrome; $\mathrm{CVD}$ : cardiovascular disease; $\mathrm{SpO}_{2}$ : peripheral oxygen saturation; $\mathrm{FiO}_{2}$ : fraction of inspired oxygen; WBC: white blood cell; RDW: red cell distribution width. 